IRA-International Journal of Applied Sciences ISSN 2455-4499; Vol.06, Issue 03 (2017)

Institute of Research Advances

Pg. no. 94-105

https://research-advances.org/index.php/IRAJAS

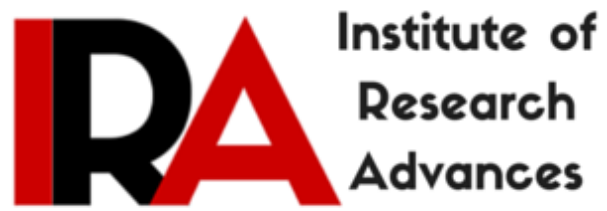

\title{
A Comparative Electrochemical Behaviour Study of p-nitrophenol Using GC and Pt Electrode
}

\section{Sangita Gupta}

Department of Chemistry, GTC Jaipur, Rajasthan, Rajasthan, India.

Type of Review: Peer Reviewed.

DOI: http://dx.doi.org/10.21013/jas.v6.n3.p4

\section{How to cite this paper:}

Gupta, S. (2017). A Comparative Electrochemical Behaviour Study of p-nitrophenol Using GC and Pt Electrode. IRA-International Journal of Applied Sciences (ISSN 24554499), 6(3), 94-105. doi:http://dx.doi.org/10.21013/jas.v6.n3.p4

(C) Institute of Research Advances

\section{(cc) EY-No}

This work is licensed under a Creative Commons Attribution-Non Commercial 4.0 International License subject to proper citation to the publication source of the work.

Disclaimer: The scholarly papers as reviewed and published by the Institute of Research Advances (IRA) are the views and opinions of their respective authors and are not the views or opinions of the IRA. The IRA disclaims of any harm or loss caused due to the published content to any party. 


\section{ABSTRACT}

The work reports a comparative electrochemical behavior study of p-nitrophenol using GC and Pt electrode. For this purpose, Cyclic Voltammetry was employed, where the redox mechanisms could be compared for reduction processes of p-nitrophenol by analysis of the voltammetric responses. Voltammetric curves of p-nitrophenol in aqueous-methanol medium on different $p H$ using B.R. buffer for various concentrations $(0.05 \mathrm{mM}, 0.1 \mathrm{mM}, 0.15 \mathrm{mM}, 0.2 \mathrm{mM})$ and scan rates at GC and Pt electrode was obtained. The very complicated reduction of p-nitrophenol revealed three reduction peaks out of which two peaks are irreversible and one peak is reversible.

Equation 1

$\mathrm{HOC}_{6} \mathrm{H}_{4} \mathrm{NO}_{2}+\mathrm{e}^{-} \rightleftharpoons \mathrm{HOC}_{6} \mathrm{H}_{4} \mathrm{NO}_{2}{ }^{-}$

Equation 2

$\mathrm{HOC}_{6} \mathrm{H}_{4} \mathrm{NO}_{2} \bullet^{-}+\mathrm{HOC}_{6} \mathrm{H}_{4} \mathrm{NO}_{2} \rightleftharpoons \mathrm{HOC}_{6} \mathrm{H}_{4} \mathrm{NO}_{2} \mathrm{H}^{\cdot}+{ }^{-} \mathrm{OC}_{6} \mathrm{H}_{4} \mathrm{NO}_{2}$

Equation 3

$\mathrm{HOC}_{6} \mathrm{H}_{4} \mathrm{NO}_{2} \mathrm{H}^{\cdot}+\mathrm{HOC}_{6} \mathrm{H}_{4} \mathrm{NO}_{2} \bullet^{-} \quad \rightleftharpoons \mathrm{HOC}_{6} \mathrm{H}_{4} \mathrm{NO}_{2} \mathrm{H}^{-}+\mathrm{HOC}_{6} \mathrm{H}_{4} \mathrm{NO}_{2}$

Equation4

$\mathrm{HOC}_{6} \mathrm{H}_{4} \mathrm{NO}_{2} \mathrm{H}^{-} \quad+\mathrm{HOC}_{6} \mathrm{H}_{4} \mathrm{NO}_{2} \rightleftharpoons \mathrm{HOC}_{6} \mathrm{H}_{4} \mathrm{NO}+{ }^{-} \mathrm{OC}_{6} \mathrm{H}_{4} \mathrm{NO}_{2}+\mathrm{H}_{2} \mathrm{O}$

The result obtained from GC electrode proved to be better than Pt electrode. Hence the GC electrode can be considered a suitable tool for determination of redox mechanism of p-nitrophenol.

Keywords: Electrochemical reduction, p-nitrophenol, Cyclic Voltammetry, TLC., IR spectra.

\section{INTRODUCTION}

Nitrophenols are used extensively in production of pesticides, dyes and pharmaceuticals. Therefore they broadly distribute in soil and aquatic environment and difficult to degrade because of their high stability. In particular p-nitrophenol is one of the priority pollutant includes in the US environmental protection agency [1-3]. The p-nitrophenolhas been detected not only in industrial waste water but also in fresh water and marine environment. It is considered a hazardous pollutant with toxic effects on human health and the environment [4].

Numerous investigations have been made on the reduction of aromatic nitro compounds [5-7]. The nitro compounds one of the best electrophores as regards to both ease of reduction and versatility of derived products. By electro reduction [5] of nitrophenol isomer using tationary and rotating $\mathrm{Cu}$ electrodes and $\mathrm{Ti}\left(\mathrm{SO}_{4}\right)_{2}$ as additional agents, aminophenols were obtained in good yield. Depending on the electrolysis conditions, a great verity of products can be obtained by electro reduction of p-nitrophenol [817]. The present work deal with the comparative voltammetric studies of p-nitrophenol at GC and Pt electrode were carried out in acidic, basic and natural medium for different concentrations and scan rates. 


\section{EXPERIMENTAL}

Solutions were prepared from AR methanol and double distilled water. Reagents used were of AR grade. p-nitrophenol was crystallized from methanol and the colorless (m.p. $114^{\circ} \mathrm{C}$ ) were used. The purity was checked by single spot TLC. IR spectra of p-nitrophenol to confirm the Sstructure.

Cyclic voltammetric studies were carried out using a three electrode cell assembly having GC/Pt as the working electrode, $\mathrm{Ag} / \mathrm{AgCl}$ as reference electrode and $\mathrm{Pt}$ wire as the counter electrode. Voltammograms of p-nitrophenol are recorded in 1:1 (v/v) water : methanol at $0.05,0.1,0.15$ and $0.2 \mathrm{mM}$ concentrations. B.R. Buffer was used to maintain desired $\mathrm{pH}$ viz. 3.4, 7.01, 9.4, 12.

\section{RESULT AND DISCUSSION}

Cyclic voltammograms were recorded with an applied potential $0.0 \mathrm{~V}$ initial potential $0.5 \mathrm{~V}$ and final potential $-1.3 \mathrm{~V}$ at different, $\mathrm{pH}$, concentrations and scan rates. Table- $1 \& 2$ summarized the voltammetric data for p-nitrophenol in acidic, basic as well as in neutral medium for $90 \mathrm{mV} / \mathrm{sec}$ scan rate at GC and $\mathrm{Pt}$ electrode.

\section{CONCLUSION}

Electrochemical reduction of p-nitrophenol is tangible in basic medium for GC electrode and due to this three prominent reduction peaks are obtained out of which one reduction peak is reversible. This proves that the Glassy Carbon electrode is better explained the electrochemical reduction of p-nitrophenol than Pt electrode.

\section{REFERENCES}

1. National Toxicology program. Toxicology and carcinogenesis studies of p-nitrophenol(CAS No. 100-02-7) in Swiss Webster Mice (Dermal studies). TR - 417.1993.

2. Agency for Toxic Substance and Disease Registry (ADSDR). Toxicological Profile for Nitrophenols (Draft). Public Health Service, U.S. Department of Health and Human Service, Atlanta, GA, 1990.

3. U.S. Environmental Protection Agency. Integrated Risk Information System (IRIS) on pnitrophenol. National center for Environmental Assessement, Office of Research and development, Wahington, DC. 1999.

4. R.Wissiak, E. Rosenberg, J. Chromatogr. A. 9. USEPA, "Health and Environmental effect profile for nitrophenols",Environmental protection Agency, January 2011.

5. Anantharman PN and Udupa HVK. Trans SAEST 1980; 15(1): 41.

6. Steven H Cadle, Paul R Tice and James Q Chambers. J Phys Chem 1967; 71: 3571.

7. Noel M, AnantharmanPN and Udupa HVK. J Appl Electrochem 1982; 12:291.

8. Tondon Anjali, Verma PS, Mukharjee SK and Tondon KN. Trans SAEST 1991; 26: 141.

9. Gurjar VS, Verma PS, Mukharjee SK and Tondon KN. Trans SAEST 1993; 28: 145.

10. Singhal Nidhi, Sharma IK and Verma PS. Trans SAEST 1997; 32: 77.

11. Malik Rakhi, , Sharma IK and Verma PS. Bull Electrochem 1999; 15(12): 529-530.

12. Yadav SR,Yadav R, Sharma A, Sharma IK and Verma PS. Bull Electrochem 2002a; 18(2): 8790.

13. Yadav SR, Goyal P, Sharma A, Sharma IK and Verma PS. J Ind Chem Soc 2002b; 79; 695-697.

14. Vijay Meenu, Sharma A, Sharma IK and Verma PS. J Electrochem Soc India 2006;55(2/3): 7077. 
15. Vijay Meenu, Kharia Nemichand, Varshney S and Verma PS. J Ind Chem Soc 2007; 46A(5); 778-782.

16. Gupta Sangita, Gupta Manish and Verma PS. Int. J App Chem 2009;15(3): 161-167.

17. Gupta Sangita, Gupta Manish, Agrawal Hemlata and Verma PS. J Ind Chem Soc 2010; 87: 5. 
(Tables \& Figures)

Table 1 Current - Potential measurement in Cyclic Voltammetry at Glassy Carbon Electrode

$\mathrm{X}$-axis $=0.1 \mathrm{~V} / \mathrm{cm} \quad$ Applied $\mathrm{E}=0.0 \mathrm{~V} \quad+\mathrm{E}=0.5 \mathrm{~V} \quad-\mathrm{E}=-1.3 \mathrm{~V} \quad$ scan rate $=90 \mathrm{mV} / \mathrm{s}$

\begin{tabular}{|c|c|c|c|c|c|c|}
\hline \multirow{2}{*}{ pH } & \multirow{2}{*}{$\begin{array}{c}\text { Concentration } \\
(\mathbf{m M})\end{array}$} & \multirow{2}{*}{ Fig.No. } & \multicolumn{3}{|c|}{ Cathodic wave } & \multirow{2}{*}{ Remark } \\
\hline & & & $\begin{array}{c}\text { Wave } \\
\text { no. }\end{array}$ & Potential (V) & $\begin{array}{c}\text { Current } \\
((\mu \mathrm{A})\end{array}$ & \\
\hline \multirow{3}{*}{3.4} & \multirow{3}{*}{0.1} & \multirow{3}{*}{ Fig. 1} & I & Not appeared & & \multirow[t]{3}{*}{$\begin{array}{c}\text { All cathodic waves are } \\
\text { irreversible }\end{array}$} \\
\hline & & & II & -0.4 & 9.0 & \\
\hline & & & III & -0.75 & 16.0 & \\
\hline \multirow{3}{*}{7} & \multirow{3}{*}{0.1} & \multirow{3}{*}{ Fig. 2} & I & -0.1 & 2.0 & \multirow[t]{3}{*}{$\begin{array}{c}\text { All cathodic waves are } \\
\text { irreversible }\end{array}$} \\
\hline & & & II & -0.6 & 15.0 & \\
\hline & & & III & -1.0 & 43.0 & \\
\hline \multirow{3}{*}{12} & \multirow{3}{*}{0.05} & \multirow{3}{*}{ Fig. 3} & I & -0.13 & 2.0 & \multirow[t]{3}{*}{$\begin{array}{l}\text { First cathodic wave is } \\
\text { reversible and other two } \\
\text { are irreversible }\end{array}$} \\
\hline & & & II & -0.83 & 16.0 & \\
\hline & & & III & -1.13 & 26.0 & \\
\hline
\end{tabular}


Table 2 Current - Potential measurement in Cyclic Voltammetry at Pt Electrode

$\mathrm{X}$-axis $=0.1 \mathrm{~V} / \mathrm{cm} \quad$ Applied $\mathrm{E}=0.0 \mathrm{~V} \quad+\mathrm{E}=0.5 \mathrm{~V} \quad-\mathrm{E}=-1.3 \mathrm{~V} \quad$ scan rate $=90 \mathrm{mV} / \mathrm{s}$

\begin{tabular}{|c|c|c|c|c|c|c|}
\hline \multirow{2}{*}{ pH } & \multirow{2}{*}{$\begin{array}{c}\text { Concentration } \\
\qquad(\mathbf{m M})\end{array}$} & \multirow{2}{*}{ Fig.No. } & \multicolumn{3}{|c|}{ Cathodic wave } & \multirow{2}{*}{ Remark } \\
\hline & & & $\begin{array}{c}\text { Wave } \\
\text { no. }\end{array}$ & $\begin{array}{c}\text { Potential } \\
\text { (V) }\end{array}$ & $\begin{array}{c}\text { Current } \\
((\mu \mathrm{A})\end{array}$ & \\
\hline 3.4 & 0.1 & & & & & No cathodic waves obtained \\
\hline \multirow{3}{*}{7} & \multirow{3}{*}{0.1} & \multirow{3}{*}{ Fig.4 } & I & -0.12 & 1.25 & \multirow[t]{3}{*}{$\begin{array}{l}\text { Only two cathodic waves are } \\
\text { appeared and they are } \\
\text { irreversible }\end{array}$} \\
\hline & & & II & -0.62 & 9.5 & \\
\hline & & & III & \multicolumn{2}{|c|}{ Not appeared } & \\
\hline \multirow{3}{*}{12} & \multirow{3}{*}{0.05} & \multirow{3}{*}{ Fig.5 } & I & -0.14 & 1.75 & \multirow{3}{*}{$\begin{array}{l}\text { Only two cathodic waves are } \\
\text { appeared. I cathodic wave is } \\
\text { reversible and II wave is } \\
\text { irreversible }\end{array}$} \\
\hline & & & II & -0.67 & 11 & \\
\hline & & & III & \multicolumn{2}{|c|}{ Not appeared } & \\
\hline
\end{tabular}


Table 3 Comparison between Glassy Carbon and Pt electrode

\begin{tabular}{|c|c|c|c|}
\hline $\mathbf{p H}$ & $\begin{array}{c}\text { Concentration } \\
(\mathbf{m M})\end{array}$ & Glassy Carbon electrode & Pt electrode \\
\hline 3.4 & 0.1 & Two cathodic waves are obtained & No cathodic waves \\
\hline 7 & 0.1 & Three cathodic waves are obtained & Only two cathodic waves are \\
obtained
\end{tabular}




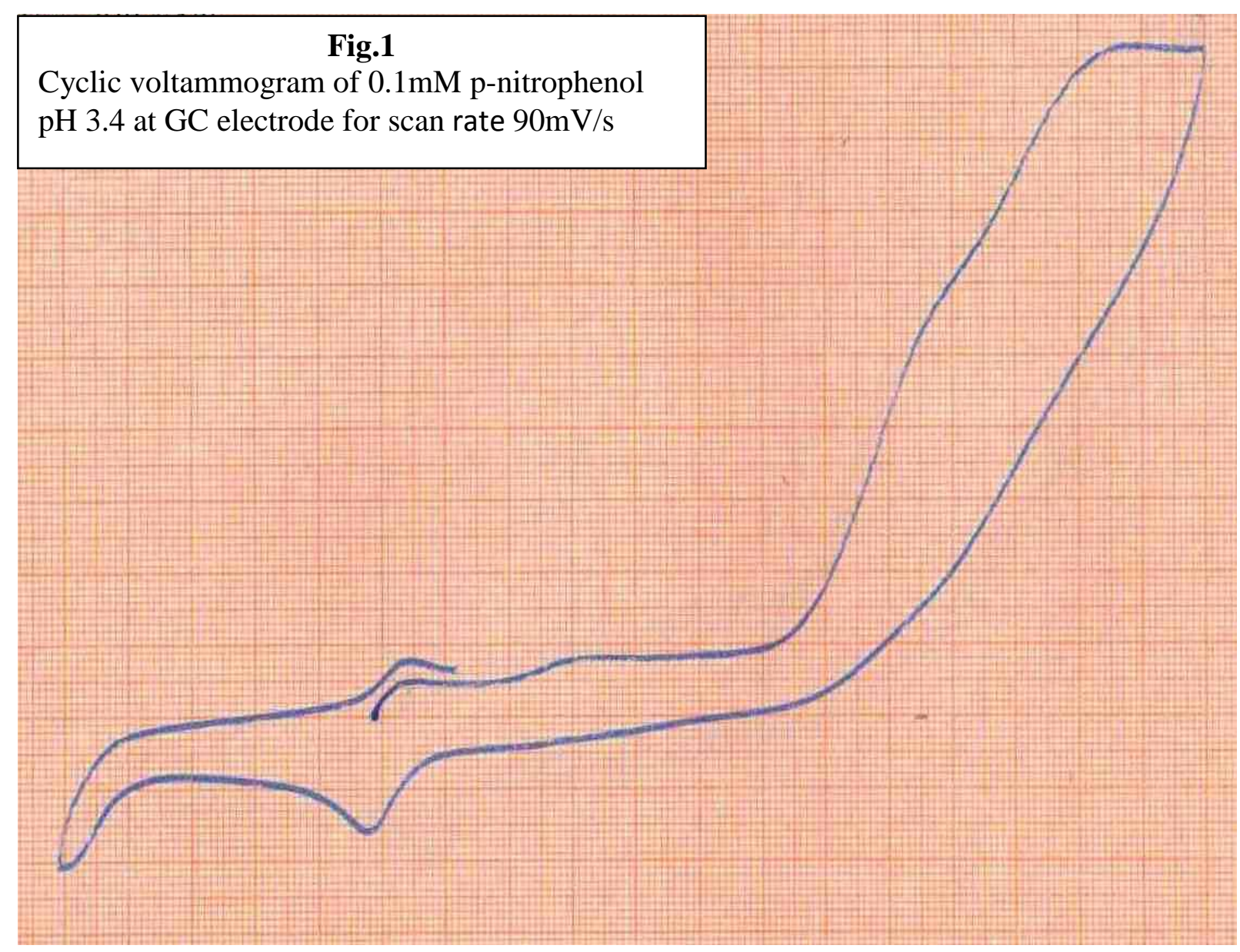




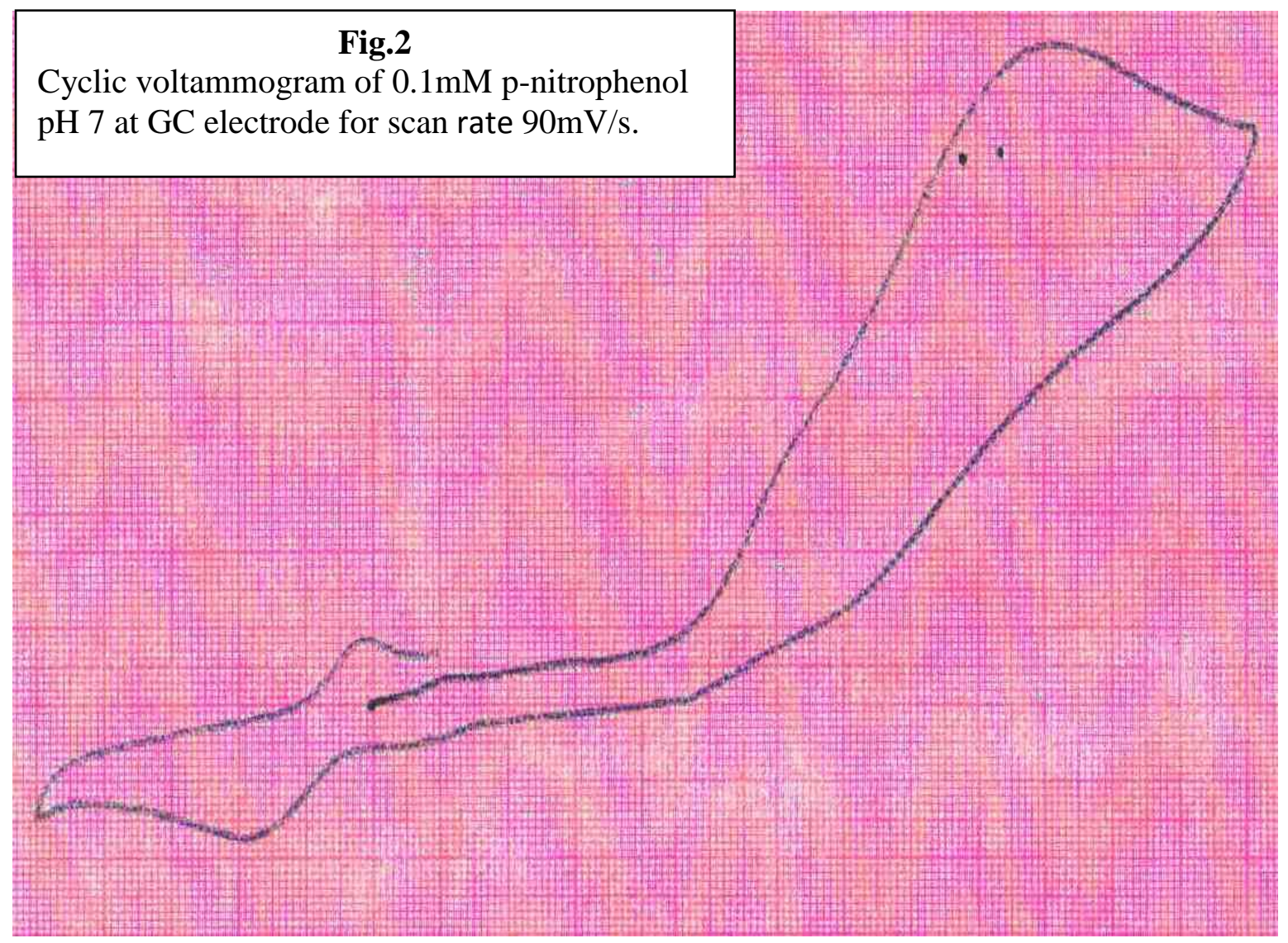


Fig.3

Cyclic voltammogram of $0.05 \mathrm{mM}$ p-nitrophenol $\mathrm{pH} 12$ at $\mathrm{GC}$ electrode for scan rate $90 \mathrm{mV} / \mathrm{s}$.

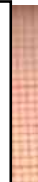

(a) $90 \mathrm{mVV} / \mathrm{s}$

(b) $80 \mathrm{mV} / \mathrm{s}$

(c) $70 \mathrm{mV} / \mathrm{s}$

(d) $60 \mathrm{mV} / \mathrm{s}$

(e) $50 \mathrm{mV} / \mathrm{s}$

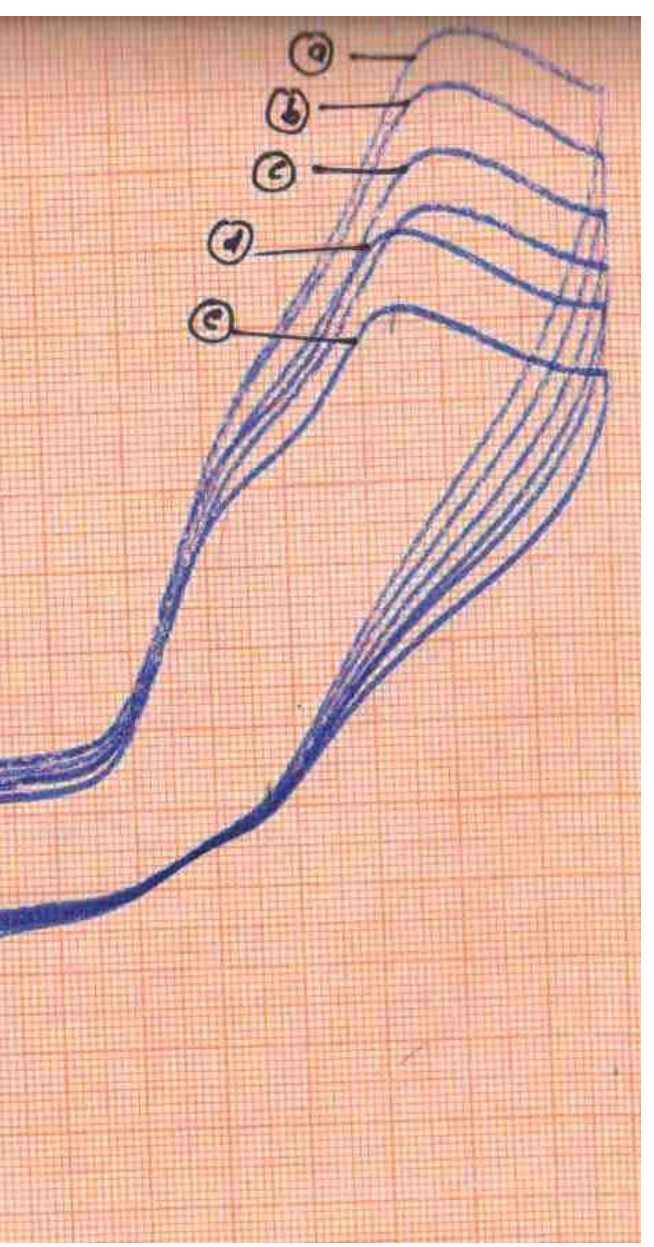




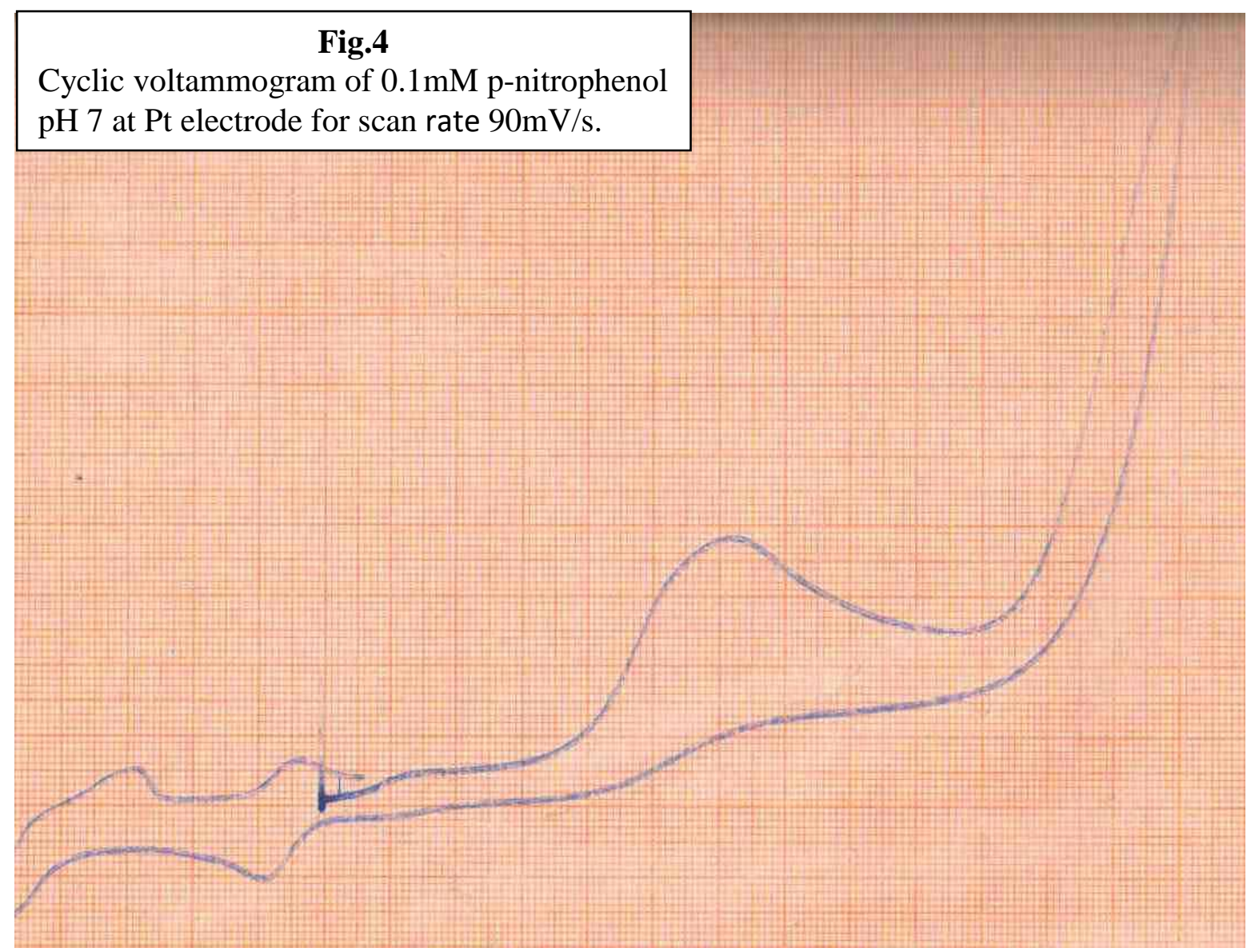




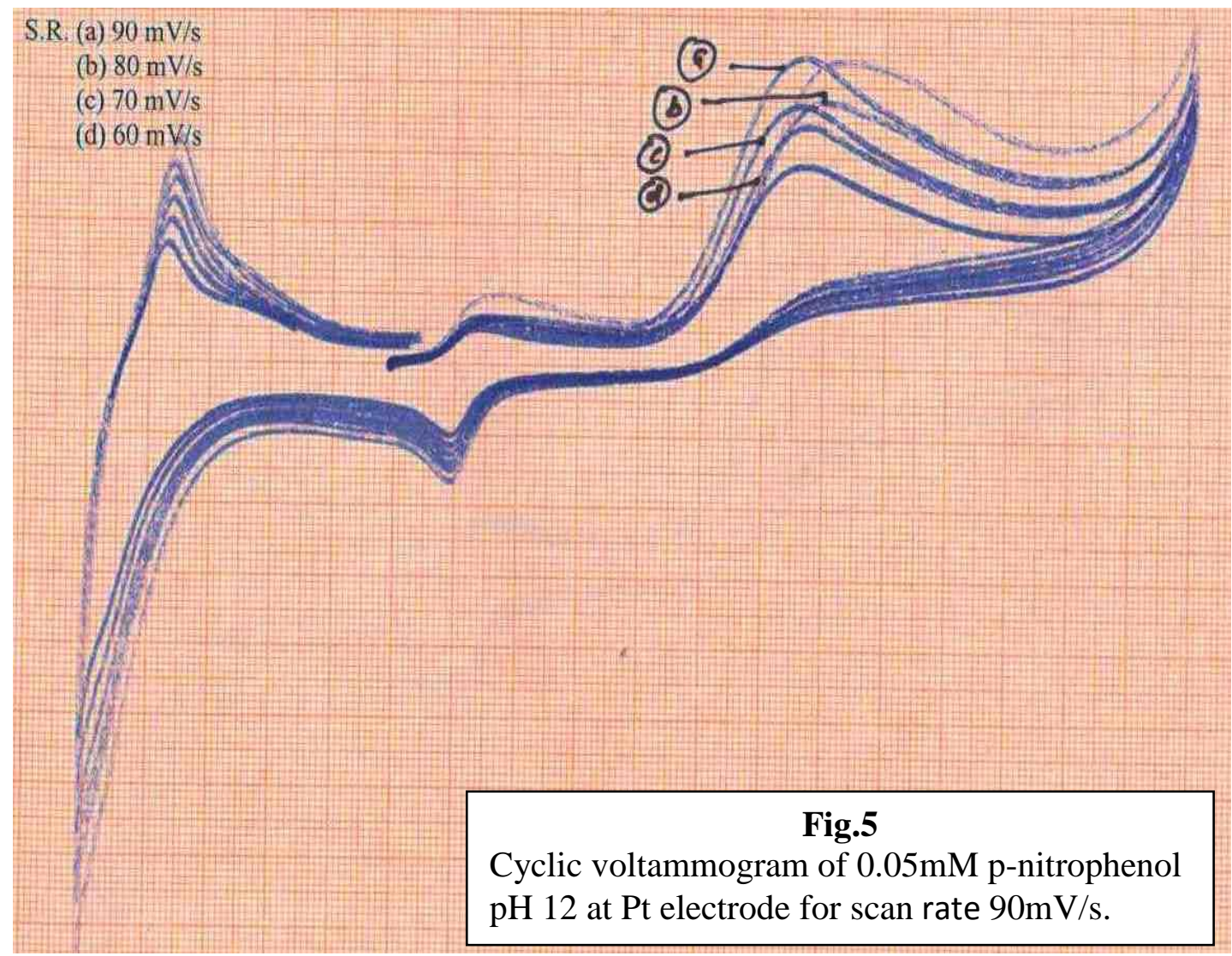

